\title{
THE RAT TESTIS AFTER VASECTOMY
}

\author{
W. B. NEAVES \\ Department of Cell Biology, University of Texas Southwestern Medical School, \\ 5323 Harry Hines Boulevard, Dallas, Texas 75235, U.S.A.
}

(Received 17th September 1973)

\begin{abstract}
Summary. Groups of rats were assigned respectively to one of six unilateral surgical treatments: scrotal sham operation, scrotal vasectomy without ligation, scrotal vasectomy with ligation, abdominal sham operation, abdominal vasectomy without ligation, and abdominal vasectomy with ligation. Three months later, the mean testis weight was unaffected by the various operative procedures, but the variance of testis weight was greater following vasectomy with ligation of the ductus deferens and after operations involving the abdominal approach. Mean testicular sperm concentrations were similar in all groups, but variance of this parameter was increased after abdominal operations. While vasectomy appears to be relatively harmless, certain procedures, such as abdominal vasectomy with ligation, disturb the rat testis more than others.
\end{abstract}

\section{INTRODUCTION}

Reduced testis weight or impaired spermatogenesis has been reported in the rat following vasectomy (Jhaver \& Ohri, 1960; Laumas \& Uniyal, 1967; Sadi, Chiorboli \& Saad, 1967; Rümke \& Titus, 1970; Altwein \& Gittes, 1972; Thakur, Sheth \& Rao, 1972; Sackler, Weltman, Pandhi \& Schwartz, 1973), while others have observed no abnormal changes (Smith, 1962; Kar, Chandra \& Kamboj, 1965; Lee, 1967; Kubota, 1969; Flickinger, 1972; Segal, 1972). The opposing evidence provided by these studies has resulted in a search for explanations. Procedural differences have been considered, since some workers used an abdominal and others a scrotal approach for vasectomy, and some blocked the ductus deferens while others did not. Few investigations were designed to discriminate between testicular changes following surgically induced cryptorchism and those attributable to vasectomy itself.

In the present study, the effects of unilateral scrotal and abdominal vasectomy with and without ligation of the ductus deferens have been compared in an experimental situation which allowed early identification of cryptorchism.

\section{MATERIALS AND METHODS}

A total of 140 adult male Holtzman rats, all aged 2 months, were obtained from the breeders in Madison, Wisconsin. One week later, the rats were randomly assigned to six groups, each group containing twenty-two to twenty- 
four rats. The rats in four of the groups were vasectomized while those in the remaining two groups were subjected to sham-operation. The four vasectomy procedures tested were scrotal vasectomy with and without ligation and abdominal vasectomy with and without ligation. External controls were provided by the scrotal and abdominal sham operations. Internal controls were provided by the contralateral intact organs.

The rats were anaesthetized with an intraperitoneal injection of aqueous chloral hydrate $(36 \mathrm{mg} / \mathrm{ml} / 100 \mathrm{~g}$ body weight). Using a sterile technique, the ductus deferens was exposed through an incision about $2 \mathrm{~cm}$ long. In scrotal procedures, the incision was continued through the tunica vaginalis to expose the left ductus deferens near the cauda epididymidis. With the abdominal approach, a mid-line suprapubic incision allowed a loop of the left ductus deferens near the ampulla to be drawn into view. In both cases, the sheath of the ductus deferens was slit and, with the accompanying artery, was gently stripped from a 1-cm segment of ductus deferens. In simple vasectomy, the free segment of ductus was excised without ligation. In ligation procedures, the proximal and distal extremes of the free segment were securely tied with 4-0 silk and the intervening ductus was excised. The wounds were closed with chromic gut and autoclips. Sham operations were performed identically except that the ductus deferens was not separated from its sheath, excised, or ligated.

From the end of the lst week after the operation until the end of the experiment, each rat's scrotum was palpated daily, and general health was noted. All ill or cryptorchid rats were excluded from the experiment.

Three months after surgery, each rat was weighed and then killed by decapitation. The right and left testes were removed and weighed to the nearest $0.005 \mathrm{~g}$, and each testis was symmetrically divided longitudinally. One-half was weighed and forced through a 100-mesh stainless steel sieve and suspended in $5 \mathrm{ml}$ physiological saline. A 1:10 dilution of this suspension was examined in a phase-contrast haemocytometer, where all mature spermatids and spermatozoa were counted in four $0.1 \mathrm{~mm}^{3}$ grids. The total number of spermatozoa counted in each dilution averaged around 200. The accuracy of the count was better than $10 \%$ as determined by reproducibility of counts on duplicate dilutions of the same suspension. Haemocytometer counts were converted to millions of spermatozoa per $\mathrm{g}$ testis. Right and left epididymides and sperm cysts were also weighed to the nearest $0.005 \mathrm{~g}$.

In each of the six groups, the means of right and left testis weight, testicular sperm concentration, and epididymis weight were compared by Gosset's $t$ test. Means of body weight, left testis weight, left testicular sperm concentration, and left epididymis weight were compared among all six groups by Fisher's one-way analysis of variance. The difference between sample variance in the groups subjected to sham-operation and in the scrotal and abdominal vasectomy groups was tested by the $F$ distribution. In all statistical tests, differences were considered significant only if $P<0.05$.

\section{Illness}

\section{RESULTS}

Fourteen $(10.0 \%)$ of the rats that began the experiment were removed from 
their groups due to illness or death before termination of the experiment. Twelve of these developed respiratory infections early in the postoperative period, one died of uraemia associated with a vesicular calculus, and one died of an undetermined cause. Autopsy of these rats did not reveal any abnormality associated with the experimental procedure.

\section{Cryptorchism}

Nine $(6.4 \%)$ of the rats developed cryptorchism following surgery. Five of the nine became cryptorchid on the right (control) side, three on the left side, and one on both sides. Only the scrotal vasectomy group did not yield an instance of cryptorchism. A single case of right-sided cryptorchism occurred in each of the other five groups. The group subjected to scrotal sham-operation developed the only example of bilateral cryptorchism. All three cases of leftsided cryptorchism occurred in the abdominal vasectomy group, which exhibited the highest incidence of abnormality. Cryptorchid testes were sig-

Table 1. Body weight, testis weight, testicular sperm concentration and epididymis weight after unilateral vasectomy in rats

\begin{tabular}{|c|c|c|c|c|c|c|}
\hline Treatment & $\begin{array}{l}\text { No. } \\
\text { of } \\
\text { rats }\end{array}$ & Side* & $\begin{array}{c}\text { Body } \\
w t^{\dagger} \\
(g)\end{array}$ & $\begin{array}{l}\text { Testis } \\
w t \dagger \\
(g)\end{array}$ & $\begin{array}{c}\text { Testicular } \\
\text { sperm } \\
\text { concentration } \dagger \\
\left(10^{6} / g\right)\end{array}$ & $\begin{array}{c}\text { Epididymi } \\
w t^{\dagger} \\
(m g)\end{array}$ \\
\hline Scrotal sham operation & 19 & $\begin{array}{l}\text { Right } \\
\text { Left }\end{array}$ & $481 \pm 9$ & $\begin{array}{l}1.79 \pm 0.07 \\
1.92 \pm 0.03\end{array}$ & $\begin{array}{l}29 \cdot 1 \pm 2 \cdot 7 \\
31 \cdot 9 \pm 1 \cdot 6\end{array}$ & $\begin{array}{l}645 \pm 21 \\
654 \pm 13\end{array}$ \\
\hline $\begin{array}{l}\text { Scrotal vasectomy } \\
\text { without ligation }\end{array}$ & 21 & $\begin{array}{l}\text { Right } \\
\text { Left }\end{array}$ & $490 \pm 8$ & $\begin{array}{l}1.93 \pm 0.03 \\
1.93 \pm 0.04\end{array}$ & $\begin{array}{l}27 \cdot 6 \pm 1 \cdot 5 \\
27 \cdot 4 \pm 1 \cdot 3\end{array}$ & $\begin{array}{l}658 \pm 7 \\
640 \pm 13\end{array}$ \\
\hline $\begin{array}{l}\text { Scrotal vasectomy with } \\
\text { ligation }\end{array}$ & 20 & $\begin{array}{l}\text { Right } \\
\text { Left }\end{array}$ & $493 \pm 10$ & $\begin{array}{l}1.93 \pm 0.04 \\
1.88 \pm 0.06\end{array}$ & $\begin{array}{l}28 \cdot 8 \pm 1.8 \\
29.2 \pm 1.7\end{array}$ & $\begin{array}{l}672 \pm 11 \\
635 \pm 17\end{array}$ \\
\hline $\begin{array}{l}\text { Abdominal sham } \\
\text { operation }\end{array}$ & 19 & $\begin{array}{l}\text { Right } \\
\text { Left }\end{array}$ & $482 \pm 9$ & $\begin{array}{l}1.98 \pm 0.07 \\
1.83 \pm 0.08\end{array}$ & $\begin{array}{l}26 \cdot 7 \pm 1 \cdot 6 \\
24 \cdot 1 \pm 2 \cdot 7\end{array}$ & $\begin{array}{l}663 \pm 11 \\
630 \pm 22\end{array}$ \\
\hline $\begin{array}{l}\text { Abdominal vasectomy } \\
\text { without ligation }\end{array}$ & 18 & $\begin{array}{l}\text { Right } \\
\text { Left }\end{array}$ & $495 \pm 8$ & $\begin{array}{l}1.80 \pm 0.05 \\
1.85 \pm 0.04\end{array}$ & $\begin{array}{l}28 \cdot 1 \pm 1 \cdot 3 \\
31 \cdot 7 \pm 1 \cdot 7\end{array}$ & $\begin{array}{l}639 \pm 18 \\
642 \pm 12\end{array}$ \\
\hline $\begin{array}{l}\text { Abdominal vasectomy } \\
\text { with ligation }\end{array}$ & 20 & $\begin{array}{l}\text { Right } \\
\text { Left }\end{array}$ & $485 \pm 12$ & $\begin{array}{l}1.80 \pm 0.07 \\
1.92 \pm 0.14\end{array}$ & $\begin{array}{l}28 \cdot 8 \pm 2 \cdot 2 \\
28 \cdot 9 \pm 2 \cdot 2\end{array}$ & $\begin{array}{l}646 \pm 20 \\
655 \pm 24\end{array}$ \\
\hline
\end{tabular}

* All surgical procedures were performed on the left side only.

$\dagger$ Expressed as mean \pm standard error.

nificantly reduced in size, averaging only $31 \%$ of the weight of the contralateral scrotal control testis.

\section{Body weight}

Analysis of variance indicated that the mean body weights (Table 1) of the six groups were not significantly different $(F=0.39)$. Comparison of each vasectomized group with its appropriate control group showed significantly elevated variance in body weight only in the case of abdominal vasectomy with ligation $(F=2 \cdot 23)$.

\section{Testis weight}

In each group, comparison of the mean right and left testis weights (Table 1) 
by the $t$ test failed to show a significant difference. The mean left testis weights of the rats in the six groups were not significantly different according to analysis of variance $(\mathrm{F}=0.39)$. A comparison of variance in left testis weight among the vasectomized rats revealed a significant $(P<0.01)$ increase in the groups with ligation. Vasectomy without ligation was not associated with a significant increase in variance of testis weight when compared with the controls. Following both sham-operation and vasectomy with ligation, a significant increase in variance occurred within the groups in which an abdominal approach was used $(F=7.03$ and 6.06 respectively).

\section{Testicular sperm concentration}

The $t$ test indicated no significant difference between right and left testicular sperm concentrations (Table 1) in each group. Similarly, analysis of variance failed to show a significant difference in the left testicular sperm concentrations of the six groups. The majority of measurements in each group fell in the range of 20 to $40 \times 10^{6}$ spermatozoa per $g$ testis. Only in the two groups subjected to sham-operation was there a significant increase in variance associated with the abdominal approach $(\mathrm{F}=2 \cdot 99)$.

\section{Epididymis weight}

The weights of the right and left epididymides were not shown to be significantly different by the $t$ test in any of the groups. Analysis of variance did not indicate a difference in the weights of the left epididymides among the groups $(F=0.32)$. Variance in the weights of the left epididymides did not appear to be significantly increased as a consequence of vasectomy in the presence or absence of ligation.

\section{Sperm cysts}

Sperm cysts averaging about $0.4 \mathrm{~g}$ each were present in all vasectomized animals at the end of the experiment. The formation of cysts did not appear to be influenced by ligation. In all scrotally vasectomized rats, the cysts had formed at the surgical site near the cauda epididymidis. Two abdominally vasectomized rats had cysts at the same location, about $3 \mathrm{~cm}$ proximal to their surgical site. All other abdominally vasectomized rats had cysts near the ampulla of the ductus deferens where the operation was performed. Sperm cyst weight exhibited a high coefficient of variation (30 to $60 \%$ ) in each vasectomized group. The mean sperm cyst weights among the four groups were not significantly different.

\section{DISCUSSION}

Variation in surgical procedure may have contributed to the diversity of findings reported in the literature on vasectomy in rats. Classification of the results according to procedural differences, however, does not dispel the disagreement that characterizes a survey of previous investigations. Abdominal vasectomy has produced both positive (Altwein \& Gittes, 1972; Sackler et al., 1973) and negative findings (Smith, 1962; Kar et al., 1965; Segal, 1972). 
Normal (Flickinger, 1972) and abnormal testes (Laumas \& Uniyal, 1967; Thakur et al., 1972) have been reported after scrotal procedures. Blockage of the ductus deferens has yielded positive (Laumas \& Uniyal, 1967; Thakur et al., 1972) and negative results (Smith, 1962; Kar et al., 1965; Flickinger, 1972; Segal, 1972). Vasectomy without ligation has produced normal (Lee, 1967) and abnormal testicular findings (Rümke \& Titus, 1970; Sackler et al., 1973).

Our study suggests that the surgical procedure of vasectomy has little influence on testicular weight or sperm concentration. The mean values of these parameters were unaffected by procedural differences, although increased variance occurred in some situations. The abdominal operation resulted in greater spread of measurements of both testis weight and testicular sperm concentration. Vasectomy with ligation of the ductus deferens significantly increased the variance in testis weight over that seen in simple vasectomy. These findings imply that some procedures, exemplified by abdominal vasectomy with ligation, disturb the rat testis more than other procedures, such as scrotal vasectomy without ligation. The nature of the disturbance, however, is such that the affected parameters may be increased as well as decreased from normal values.

The normal levels of testicular sperm concentration in our vasectomized rats indicated that vasectomy had no effect on spermatogenesis. The epididymis also was not grossly affected, although continuing sperm production did result in large sperm cysts at or proximal to the site of interference with the ductus deferens. The similar size of cysts in all vasectomized groups argues against peritoneal dispersion of spermatozoa in open vasectomy.

Our failure to find evidence of impaired spermatogenesis in rats vasectomized by various procedures suggests that reconciliation of conflicting reports in the literature must involve factors other than procedural differences. Cryptorchism, which leads rapidly to disruption of spermatogenesis and testicular atrophy, is known to occur in some vasectomized rats (Oslund, 1924). In spite of this, only a few workers (Smith, 1962; Kar et al., 1965; Segal, 1972), all of whom reported negative findings, appeared actively to have avoided cryptorchism in their vasectomized rats. None of the recent reports of testicular changes following vasectomy in rats contains references to any precautions taken against cryptorchism (Jhaver \& Ohri, 1960; Laumas \& Uniyal, 1967; Sadi et al., 1967; Rümke \& Titus, 1970; Altwein \& Gittes, 1972; Thakur et al., 1972; Sackler et al., 1973). Inadequate discrimination between the consequences of vasectomy and induced cryptorchism (Oslund, 1924) may still be responsible for much of the disagreement surrounding vasectomy in rats.

\section{ACKNOWLEDGMENTS}

This study was supported by a grant from the Population Council. We thank Dr Rupert Billingham for criticizing the manuscript and Miss Linda Barth for excellent technical assistance.

\section{REFERENCES}

Altwein, J. E. \& Grtres, R. F. (1972) Vasektomie und Hodenfunktion. Tierexperimentelle Untersuchungen. Actuelle Urologie, 3, 235.

Fuickinger, C. J. (1972) Ultrastructure of the rat testis after vasectomy. Anat. Rec. 174, 477. 
JHAVER, P. S. \& OHRI, B. B. (1960) The history of experimental and clinical work on vasectomy. 7. int. Coll. Surg. 33, 482.

Kar, A. B., Chandra, H. \& Kamboj, V. P. (1965) Long-term effect of vasectomy on the gonadpituitary system of rats. Acta biol. med. germ. 15, 381 .

Kubota, R. (1969) Electron microscopic studies of the testis after vasectomy in rats and men. $7 a p . \mathcal{F}$. Urol. 60, 373.

LAUMAS, K. R. \& UnIYAL, J. P. (1967) Disintegration of spermatozoa and testicular atrophy by a silastic block of vas deferens in rats. Indian F. exp. Biol. 5, 199.

LEE, H. Y. (1967) Studies on vasectomy. IV. Experimental studies on biological, histologic and histochemical effects of vasectomy. F. Korean med. Ass. 10, 893.

Oslund, R. (1924) A study of vasectomy on rats and guinea pigs. Am. F. Physiol. 67, 422.

RÜMKE, P. \& TrTus, M. (1970) Spermagglutinin formation in male rats by subcutaneously injected syngeneic epididymal spermatozoa and by vasoligation or vasectomy. F. Reprod. Fert. 21, 69.

Sackier, A. M., Weltman, A. S., Pandhi, V. \& Schwartz, R. (1973) Gonadal effects of vasectomy and vasoligation. Science, N.Y. 179, 293.

Sadr, A., Chrorboli, E. \& SAad, F. (1967) Vasectomia em ratos. Hospital, Rio de 7. 72, 267.

SEGAL, R. J. (1972) Effect of vasoligation of 14-day-old and 21-day-old rats on spermatogenesis. Int. J. Fert. 17, 33.

SMrTH, G. (1962) The effects of ligation of the vasa efferentia and vasectomy on testicular function in the adult rat. 7. Endocr. 23, 385.

Thakur, A. N., Sheth, A. R. \& Rao, S. S. (1972) Biochemical studies on rat testes and sex accessory organs after vasoligation operation. Fert. Steril. 23, 834. 